\title{
Imaging Core Lab
}

National Cancer Institute

\section{Source}

National Cancer Institute. Imaging Core Lab. NCI Thesaurus. Code C142815.

A shared facility for imaging services. 